\title{
高力ボルトの終局せん断強度 \\ ULTIMATE SHEAR STRENGTH OF HIGH STRENGTH BOLTS
}

\author{
橋本篤秀*, 山田丈富** \\ Atsuhide HASHIMOTO and Tomohisa YAMADA
}

In this paper, the double shear tests are carried out to determine the shear strength of single $4 \mathrm{~T}, \mathrm{~F} 8 \mathrm{~T}$, and $\mathrm{F} 10 \mathrm{~T}$ bolts and to investigate the effect of initial internal tension for the bolt shear strength, and the ultimate strength of bolts subjected to combined tension and shear loading are examined.

The results may be summarized as follows:

(1) The equation ( 8$) \sim(16)$ may be used regardless of initial internal tension to determine the shear strength of bolts. The ultimate shear load may be calculated on bolt section according to the location of the shear planes.

(2) The ultimate strength of bolts subjected to combined tension and shear loading can be represented by the ellipse equation (17).

Keywords : high strength bolt, shear strength, tensile strength, interaction, ultimate strength 高力ボルト，せん断強度，引張強度，相関関係，終局強度

\section{1. 序}

鋼構造物の高力ボルトによる接合形式には，主として 摩擦接合と引張接合がある。

高力ボルト摩擦接合では楴め付けられた接合部材間の 摩擦力で応力を伝達させるものとして，滑りを生じない 範囲で設計するようにしている。そのため高力ボルトが 直接せん断力を受けることにはならない。しかし，終局 的には滑りを生じた後高力ボルトが孔縁に接触し，ボル 卜軸部にせん断力が作用する状態になり，接合部の終局 耐力は母材の破壊か高力ボル卜のせん断破壊によって決 定される。

現在, 締め付け板厚に対する高 カボルトの首下長さの選択の基準 と JIS B 1186 による高力ボルト のねじ部寸法等の関係をとりまと めると表一1となり，ナット側の 鋼材が $12 \mathrm{~mm}$ 程度以下のときは せん断面にねじ部が存在すること があり得ることが認められる。

また，高力ボルト引張接合形式 による筋かい端接合部等のよう
に，せん断抵抗をその材間圧縮力による摩擦抵抗に期待 する場合，摩擦抵抗が無くなった後に終局状態となると きには，外的な引張力（ボルトの初張力ではない）とせ ん断力がボルトに同時に作用することになる。

したがって，ボルトの円筒部だけでなくねじ部の単純 せん断時の終局せん断応力度（以降，終局せん断強さ之 称す), およびボルトの終局強度に関する外的な引張り とせん断の相関関係を定量化することが必要である。ボ ルトの終局せん断強さに関する系統立てた実験による研 究はWallaert ら"，またボルトの強度の引張りとせん断 の相関関係に関する研究は終局強度については Ches-

表一1 高力ボルト首下長さとナット下ねじ部長さ関係

\begin{tabular}{|c|c|c|c|c|c|c|c|c|}
\hline \multirow[b]{3}{*}{ 呼び径 } & \multirow{3}{*}{$\begin{array}{l}\text { 榊付厚に } \\
\text { 加え万長さ }\end{array}$} & \multirow{2}{*}{\multicolumn{2}{|c|}{ JIS・JSSによる }} & \multirow{3}{*}{$\begin{array}{l}\text { 座金 } \\
\text { 厚さ }\end{array}$} & & & & 位： $\mathrm{m} \mathrm{m}$ \\
\hline & & & & & \multicolumn{3}{|c|}{ ナット下のねじ部長さ } & \multirow{2}{*}{$\begin{array}{l}\text { ナット下の } \\
\text { ねじ部長さ } \\
\text { の変動幅 }\end{array}$} \\
\hline & & 加部長さ & 許容差 & & 摽準最さ & $\begin{array}{l}\text { 許容差に } \\
\text { よる変動長 }\end{array}$ & 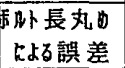 & \\
\hline M 16 & $\begin{array}{c}30 \\
\left(\begin{array}{c}25 \\
)\end{array}\right.\end{array}$ & 30 & $\begin{array}{l}+5 \\
-0\end{array}$ & 4.5 & $\begin{array}{c}9.0 \\
(9.5)\end{array}$ & $\begin{array}{l}14 \sim 9 \\
(14.5 \sim 9.5)\end{array}$ & $\begin{array}{l}+3.0 \\
-2.0\end{array}$ & $\begin{array}{c}17 \sim 7 \\
(17.5 \sim 7.5)\end{array}$ \\
\hline M 20 & $\begin{array}{l}35 \\
(30)\end{array}$ & 35 & $\begin{array}{l}+6 \\
-0\end{array}$ & 4.5 & $\begin{array}{c}9.0 \\
(9.5)\end{array}$ & \begin{tabular}{|l|}
$14 \sim 9$ \\
$(15.5 \sim 9.5)$
\end{tabular} & $\begin{array}{l}+3.0 \\
-2.0\end{array}$ & $\begin{array}{c}17 \sim 7 \\
(18.5 \sim 7.5)\end{array}$ \\
\hline M 22 & $\begin{array}{c}40 \\
(35)\end{array}$ & 40 & $\begin{array}{l}+6 \\
-0\end{array}$ & 6.0 & \begin{tabular}{|r|}
12.0 \\
$(11.0)$
\end{tabular} & $\begin{array}{c}18 \sim 12 \\
(17 \sim 11)\end{array}$ & $\begin{array}{l}+3.0 \\
-2.0\end{array}$ & $\begin{array}{l}21 \sim 10 \\
(20 \sim 9)\end{array}$ \\
\hline M 24 & $\begin{array}{c}45 \\
(40)\end{array}$ & 45 & $\begin{array}{l}+6 \\
-0\end{array}$ & 6.0 & $\begin{array}{r}12.0 \\
(11.0)\end{array}$ & $\begin{array}{l}18 \sim 12 \\
(17 \sim 11)\end{array}$ & $\begin{array}{l}+3.0 \\
-2.0\end{array}$ & $\begin{array}{l}21 \sim 10 \\
(20 \sim 9)\end{array}$ \\
\hline
\end{tabular}

（）内はトルシア型高力ボルトの場合の数值
本報の一部は, 文献 5)，6）で発表している。

*千葉工業大学建築学科 教授・博士 (工学)

**灭葉工業大学建築学科講師・修士 (工学)
Prof., Dept. of Architecture, Chiba Institute of Technology., Dr. Eng. Lecturer, Dept. of Architecture, Chiba Institute of Technology, M. Eng. 


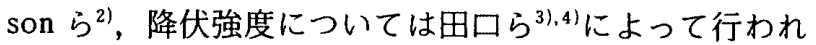
ている。

これらの既往の研究では，ボルトの終局せん断強さに 対してボルトの初張力・ボルト径・グリップ長さ・継手 板の鋼材の種類はほとんど影響しないことを明らかにし ている。さらに，せん断面位置に対応したボルトの有効 断面積によって評価をすれば，せん断面位置によらず終 局せん断強さとボルト素材の引張強さの比はほぼ等しく なるとしている。

しかし，JIS 規格のボルトを用いた著者の実験(5),6)で は，せん断面位置に対応したボルトの有効断面積によっ て評価をしても終局せん断強さとボルト素材の引張強さ の比は等しくならない結果となっている。また，ボルト の初張力の影響についてはボル卜円筒部がせん断面とな る場合のデータしかなく，初張力導入時に降伏すると予 想される杍じ部がせん断面となる場合の検討はなされて いない。

本報は, F 10 T, F 8 T の高力ボルト，および SS 400 材による $4 \mathrm{~T}$ レベルの中ボルトについて，せん断面が円 筒部およびねじ部となる場合の終局せん断強さを実験で 確認し，ボルトのせん断強さの評価式並びにそれにせん 断位置に対応したボルトの有効断面積を乗じた終局せん 断強度評価式を統計的手法により新たに提唱する。そし て，既往の研究によるデータを整理し，ボルトにせん断 力と外的引張力が同時に作用する場合の終局強度の評価 式を示す。さらに，ボルトのせん断面がねじ部となり， 初張力によりねじ部が局部的に降伏しているときの終局 せん断強さについて確認実験を行い，初張力の有無によ らずさらに称じ部については降伏状態にあっても提唱し た終局せん断強度評価式が成立することを示す。なお， 高力ボルトの単純引張時の性状については, 文献 7)，8） に発表している。

\section{2. 供試体および実験方法}

供試ボルトは, JIS B 1186 の規格品の F $10 \mathrm{~T}, \mathrm{~F} 8 \mathrm{~T}$ および溶融亜鉛めっきされた同規格を満たす F8T の高 カボルトと, JIS B 1180 の $4 \mathrm{~T}$ に該当する溶融亚鉛めっ きされたSS 400 材の中ボルトを用いた。ただし，めつ きしたボルトについてはその状態での機械的性質は，F $8 \mathrm{~T}$ 高力ボルト・4 T レベルの中ボルトともそれぞれの JIS 規格値を充足しているので，めっきによる影響は無 視した。

ボルトのせん断面位置は図一1に示すように，二せん 断面が共に円筒部となる AA 形式，一面が円筒部で一 面がねじ部となる $\mathrm{AC}$ 形式，二面共にねじ部となる CC 形式の 3 タイプとした。このせん断面位置の調整は適正 中板厚を用いるとともにボルト頭側に座金を入れて調整 した。供試体の一覧は表一 2 に示す通りであり，各ボル

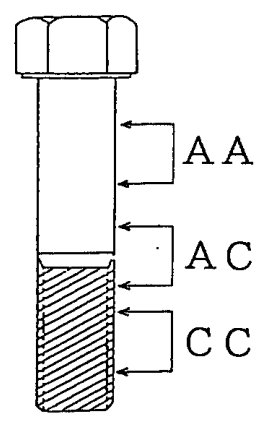

図-1 せん断面位置
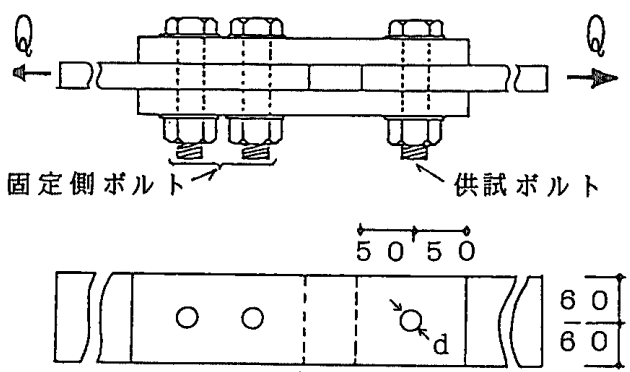

図一2 実験装置例

表一2 供試体一覽

\begin{tabular}{|c|c|c|c|c|c|c|c|}
\hline \multirow[b]{2}{*}{ 鋼種 } & \multirow[b]{2}{*}{ 2nxyキ } & \multicolumn{3}{|c|}{ ボルト } & \multicolumn{3}{|c|}{ ボルト本数 } \\
\hline & & 呼び径 & ×首 & 下舟代 & A A 形 & A C 形 & $\mathrm{C}$ C 形 \\
\hline \multirow{3}{*}{$\mathrm{F} 10 \mathrm{~T}$} & \multirow{3}{*}{ 無 } & M16 & $x$ & 85 & 6 & 6 & 6 \\
\hline & & M 20 & $x$ & 90 & 6 & 6 & 6 \\
\hline & & M 22 & $x$ & 95 & 6 & 6 & 6 \\
\hline \multirow{4}{*}{$\mathrm{F} 8 \mathrm{~T}$} & \multirow[t]{2}{*}{ 無 } & M2O & $\bar{x}$ & 90 & 6 & 0 & 6 \\
\hline & & M 22 & $x$ & 95 & 6 & 0 & 6 \\
\hline & \multirow[t]{2}{*}{ 有 } & M2O & $x$ & 90 & 6 & 6 & 6 \\
\hline & & M 22 & $\times 1$ & 00 & 6 & 6 & 6 \\
\hline \multirow{2}{*}{$\begin{array}{l}\text { S S } 400 \\
\left(4 T V \Lambda^{+} \pi\right)\end{array}$} & \multirow[t]{2}{*}{ 有 } & M 20 & $x$ & 80 & 6 & 6 & 6 \\
\hline & & M 22 & $x$ & 85 & 6 & 6 & 6 \\
\hline
\end{tabular}

表一3 供試ボルトの機械的性質

\begin{tabular}{|c|c|c|c|c|c|c|}
\hline 銅 租 & $\ln x \rightarrow \neq$ & ボルト & $\begin{array}{c}\text { 降伏点 } \\
\sigma y \\
\left(\mathrm{tf} / \mathrm{cm}^{2}\right) \\
\end{array}$ & $\begin{array}{c}\text { 引張覴さ } \\
\sigma \text { U。 } \\
\left(\mathrm{tP} / \mathrm{cm}^{2}\right)\end{array}$ & $\begin{array}{l}\text { 伸U } \\
\mathrm{BI} \\
(x) \\
\end{array}$ & $\begin{array}{c}\text { 㜞 } \\
\phi \\
(x)\end{array}$ \\
\hline \multirow{3}{*}{$\mathrm{F} 10 \mathrm{~T}$} & \multirow{3}{*}{ 無 } & M16X & 10.23 & 10.82 & 18.3 & 65.0 \\
\hline & & M2OX & 10.15 & 10.77 & 18.7 & 66.8 \\
\hline & & M22X & 9.98 & 10.68 & 18.4 & 86.5 \\
\hline \multirow{4}{*}{ F $8 \mathrm{~T}$} & \multirow[t]{2}{*}{ 無 } & M $20 \times 90$ & 8.22 & $8: 86$ & 20.5 & 71.3 \\
\hline & & M22X & 7.70 & 8.51 & 22.0 & 71.3 \\
\hline & \multirow[t]{2}{*}{ 有 } & M 20x & 7.80 & 8.62 & 24.9 & 71.2 \\
\hline & & $M 22 \times 100$ & 7.93 & 8.69 & 28.4 & 71.2 \\
\hline \multirow{2}{*}{$\begin{array}{l}S S 400 \\
\left(4 T A^{\circ} B\right)\end{array}$} & \multirow[t]{2}{*}{ 有 } & M20x & 2.94 & 4.79 & 26.9 & 68.2 \\
\hline & & M22 285 & 2.74 & 4.77 & 27.0 & 68.2 \\
\hline
\end{tabular}

表-4 ボルトと鋼材の組合せ

\begin{tabular}{|c|c|c|c|c|c|c|c|}
\hline \multirow[t]{2}{*}{ 铜租 } & \multirow{2}{*}{\begin{tabular}{|c|}
$20 x y 7$ \\
450 \\
$8 / n^{2}$
\end{tabular}} & \multirow[t]{2}{*}{ ポ几卜 } & \multicolumn{2}{|c|}{ 板军 } & (an) & \multirow{2}{*}{$\begin{array}{l}\text { 釜玨 } \\
\text { (四) }\end{array}$} & \multirow{2}{*}{ 鋼材㧋況 } \\
\hline & & & 外板 & 中板" & 外板 & & \\
\hline \multirow{3}{*}{$\mathrm{F} 10 \mathrm{~T}$} & \multirow{3}{*}{ 無 } & M18 $x$ & 12 & 22 & 12 & 17.0 & \multirow{5}{*}{ SM 490} \\
\hline & & M2OX & 12 & 22 & 12 & 21.5 & \\
\hline & & M2 $2 \times 95$ & 12 & 22 & 12 & 23.5 & \\
\hline \multirow{4}{*}{ F $8 \mathrm{~T}$} & \multirow[t]{2}{*}{ 無 } & M2OX 90 & 12 & 22 & 12 & 21.5 & \\
\hline & & M22X & 12 & 22 & 12 & 23.5 & \\
\hline & \multirow[t]{2}{*}{ 有 } & M2OX & 12 & 25 & 12 & 21.5 & \multirow{4}{*}{ 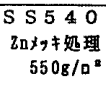 } \\
\hline & & $M 22 \times 100$ & 12 & 25 & 12 & 23.5 & \\
\hline \multirow{2}{*}{$\begin{array}{l}\text { SS } 400 \\
\left(4 \mathrm{~T}\left(1^{\circ} n\right)\right.\end{array}$} & \multirow[t]{2}{*}{ 有 } & $\mathrm{M2O} \times 80$ & 10 & 15 & 10 & 21.5 & \\
\hline & & M22X & 10 & 15 & 10 & 23.5 & \\
\hline
\end{tabular}

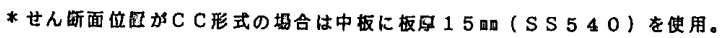

トの機械的性質（JIS Z 22014 号試験片による）は表 一3に示すとおりである。使用したボルトの呼び径は, M 16，M 20，M 22 である。同一実験に対して各 6 本ず つとした総数 150 本の供試体について実験を実施した。 
載荷は母材破断の無いように設計した図一2に例示す るような二面せん断の摩擦接合形式の試験体を用いて, $200 \mathrm{tf}$ 万能試験機を用いて単調引張りにより破断に至ら しめた。ボルトと加力用鋼板の組み合わせは表一4に示 すとおりとし, 最初はボルトの初張力は導入せず，外板 と中板にすき間のない程度に手締めした。軸力を導入し た場合については 6 項に記述している。また，実験に先 立ってボルト各部の寸法測定を行ったが，いずれも許容 寸法内にあるので，結果の整理には公称寸法を用いるこ ととした。

\section{3. 結果と考察}

各供試体について，実験による最大せん断力 $Q_{A A}$, $Q_{\mathrm{Ac}}, \dot{Q}_{\mathrm{cc}}(\mathrm{tf})$ ，これらをそれぞれのせん断面に対応し たボルトの公称断面積で除した実験による最大せん断応 力度，すなわち終局せん断強さ $\tau_{\mathrm{AA}}, \tau_{\mathrm{AC}}, \tau_{\mathrm{cC}}\left(\mathrm{tf} / \mathrm{cm}^{2}\right)$, ならびにこれらの終局せん断強さを表一 3 に示したボル ト素材の引張強さ $\sigma_{u_{0}}$ で除した值 $\left(\tau_{u} / \sigma_{u_{0}}\right)$ を示すと表 一5となる。また， AA， AC，CC 形式についての最終 破断状況例をそれぞれ写真一1〜3に示す。

ここで, 二面せん断の場合であるので, 終局せん断強さ は (2)〜（4) 式によった。

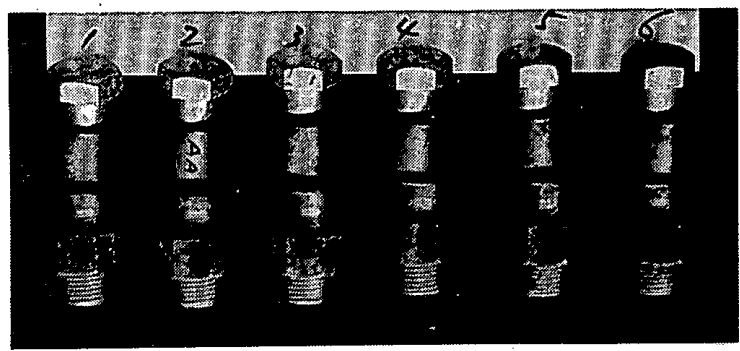

写真一1 最終破断状況（AA 形式, F 8 T Zn M 22)

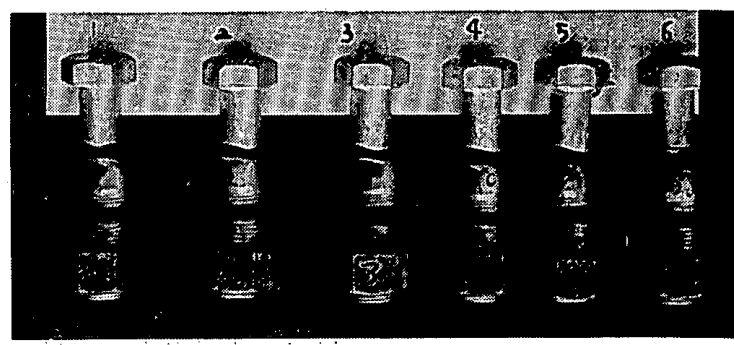

写真一2 最終破断状況 (AC 形式, F 8 T Zn M 22)

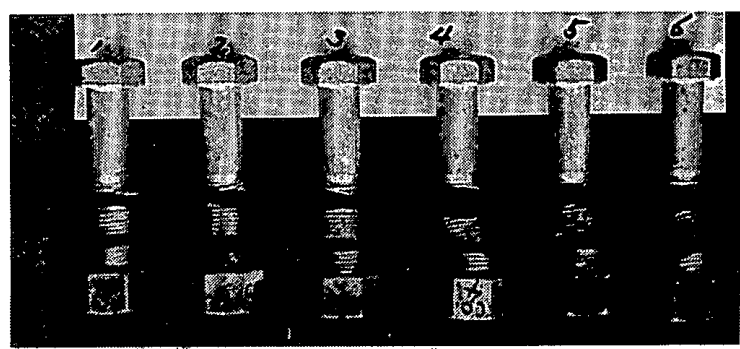

写真一3 最終破断状況（CC 形式，F.8 T Zn.M.22）

$$
\tau_{u}=\left\{\begin{array}{l}
\tau_{\mathrm{AA}}: \text { 二せん断面が共に円筒部の場合 } \\
\tau_{\mathrm{Ac}}: \text { せん断面が円筒部とねじ部の場合 } \\
\tau_{\mathrm{CC}}: \text { 二せん断面が共にねじ部の場合 }
\end{array}\right.
$$

$$
\begin{aligned}
& \tau_{\mathrm{AA}}=Q_{\mathrm{AA}} /\left(2 \mathrm{~A}_{b}\right) \cdots \\
& \tau_{\mathrm{AC}}=Q_{\mathrm{AC}} /\left(\mathrm{A}_{b}+\mathrm{A}_{e}\right) \\
& \tau_{\mathrm{CC}}=Q_{\mathrm{CC}} /\left(2 \mathrm{~A}_{e}\right) \cdots
\end{aligned}
$$

ただし， $A_{b}$ ：ボルト円筒部公称断面積 $\left(\mathrm{cm}^{2}\right)$

$\mathrm{A}_{e}$ : ボルトねじ部公称有効断面積 $\left(\mathrm{cm}^{2}\right)$

これらの結果より， $\tau_{u} / \sigma_{u_{0}}$ の值がせん断面位置および ボルトの材種により変化することが分かる。

既往の研究で取り上げられているもの以外で，ボルト の終局せん断強さに影響を与える因子として考えられる ものは, ボルト素材の引張強さ, 降伏比・伸び性能・破 壊靶性・ボルト形状・不完全ねじ部とせん断面位置の関 係等である。しかし，実用に供されている状況ではボル 卜はJIS で素材および形状が規定されており，さらに 本実験ではせん断面を確実にねじ部や円筒部になるよう にしているため, 結果の整理に際しせん断面位置および ボルト素材の引張強さとの関係に着目した。

図一3〜図一 5 に，終局せん断強さとボルト素材の引 張強さの比 $\left(\tau_{u} / \sigma_{u 0}\right)$ とボルト素材の引張強さ $\left(\sigma_{u_{0}}\right.$ $\left.\left(\mathrm{tf} / \mathrm{cm}^{2}\right)\right)$ の関係をせん断面位置ごとに示す。図中に は同一実験 6 体の平均值およびその分布域を示してい る。また，せん断面位置ごとの全デー夕に基づく回帰式 は次の $(5) \sim(7)$ 式となる。相関係数はそれぞれ, 0.79, $0.95,0.97$ である。

$$
\begin{aligned}
& \tau_{\mathrm{AA}} / \sigma_{u_{0}}=0.744-1.17 \times 10^{-2} \times \sigma_{u_{0}} \\
& \tau_{\mathrm{AC}} / \sigma_{u_{0}}=0.863-2.60 \times 10^{-2} \times \sigma_{u_{0}} \\
& \tau_{\mathrm{cc}} / \sigma_{u_{0}}=1.053-5.22 \times 10^{-2} \times \sigma_{u_{0}}
\end{aligned}
$$

なお，図中にはこれらの回帰直線と $95 \%$ 信頼域を示し

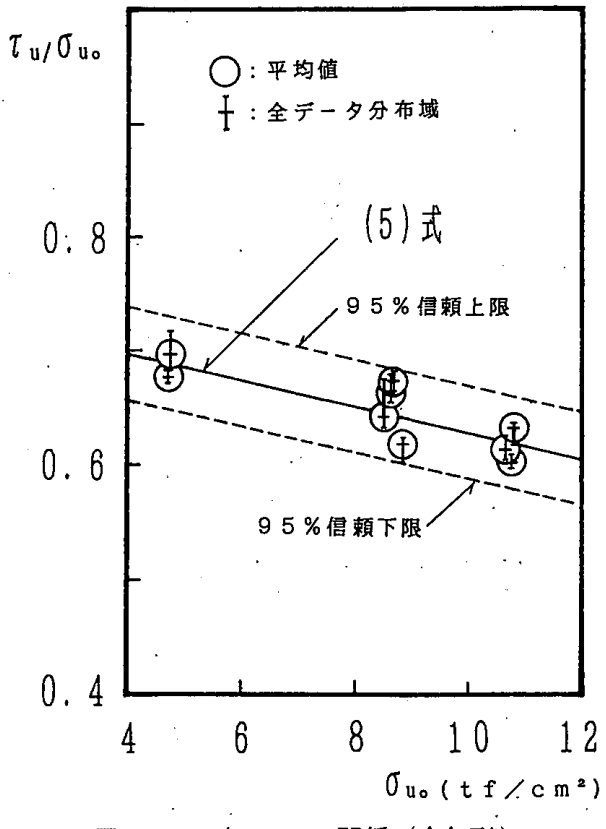

図一3 $\tau_{u} / \sigma_{u_{0}}-\sigma_{u_{0}}$ 関係 (AA 形) 


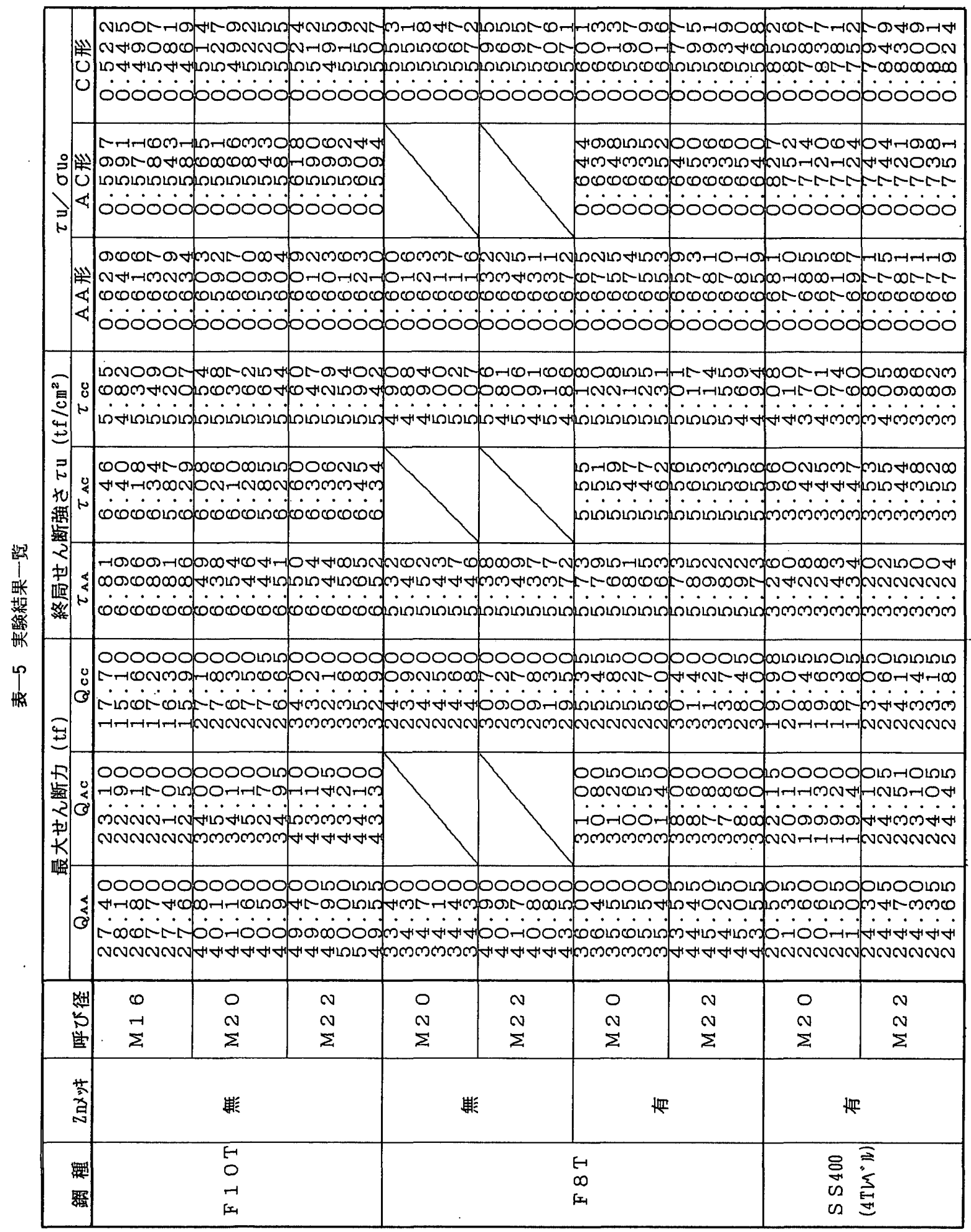

た。

これらから，せん断面位置ごとに終局せん断強さとボ ルト素材の引張強さの比 $\left(\tau_{u} / \sigma_{u_{0}}\right)$ とボルト素材の引張 強さ $\left(\sigma_{t_{0}}\right)$ に非常に強い相関関係があることが認めら れる。

$\mathrm{AA}$ 形式では, $\tau_{u} / \sigma_{u_{0}}$ の平均值はボルト素材の引張強 さ $\left(\sigma_{u_{0}}\right)$ の増大とともに 0.7 から 0.6 に減少している。 さらに，衫じ部がせん断面となるとボルト素材の引張強 さ $\left(\sigma_{u_{0}}\right)$ の影響が大きくなり，CC 形式では，4Tレベ
ルのボルトで $\tau_{u} / \sigma_{u_{0}}$ の平均值は約 $0.8, \mathrm{~F} 10 \mathrm{~T}$ で約 0.5 となっている。

これらのことから, せん断面の面積としてせん断面に 対応した公称有効断面積を用いる前提に立てば，ボルト 素材の引張強さの違いだけでなく，せん断面位置が円筒 部かねじ部によって終局せん断強さを修正する必要があ ると言える。

図一6は，既往の文献1).21に示されている実験結果の うち，本報と同じ載荷形式を採っている実験で AA 形 


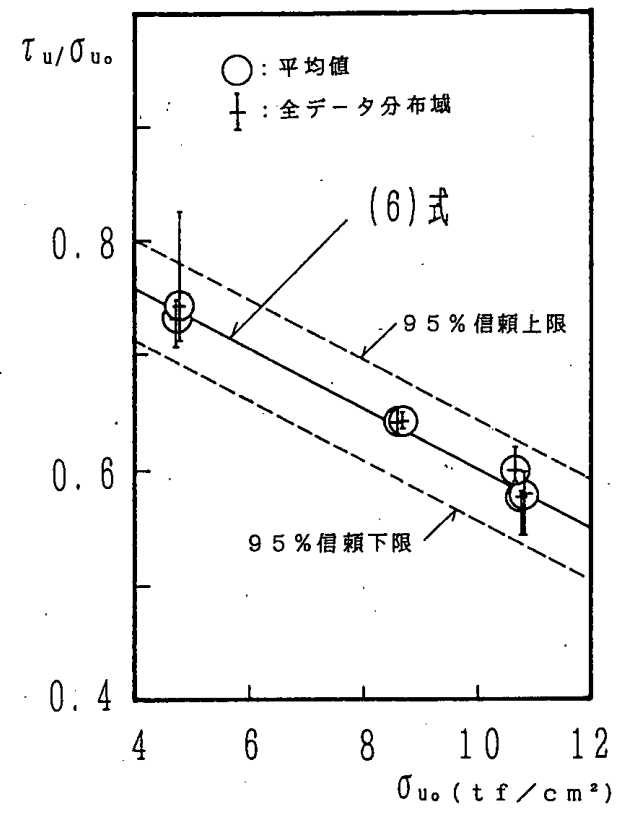

図-4 $\tau_{u} / \sigma_{u_{0}}-\sigma_{u_{0}}$ 関係 (AC 形)

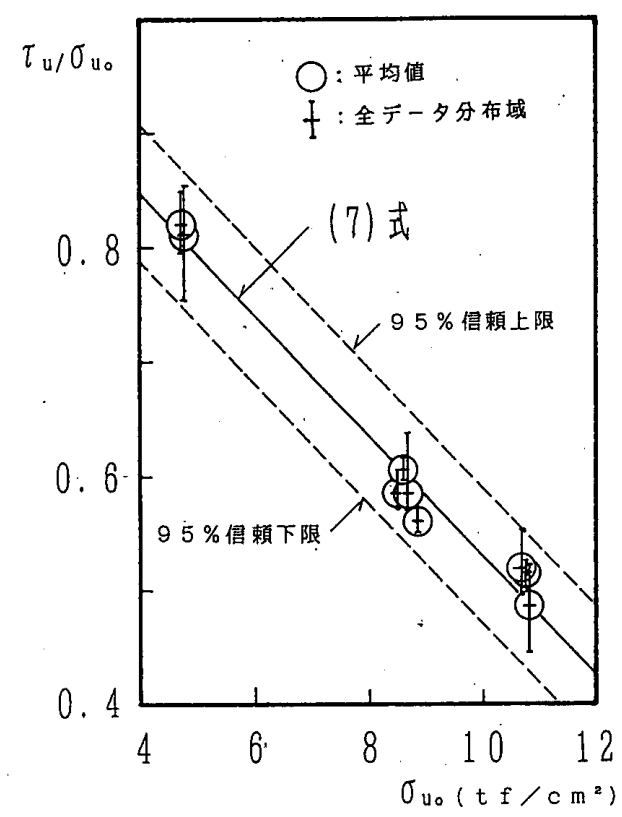

図一5 $\tau_{u} / \sigma_{u_{0}}-\sigma_{u_{0}}$ 関係 (CC 形)

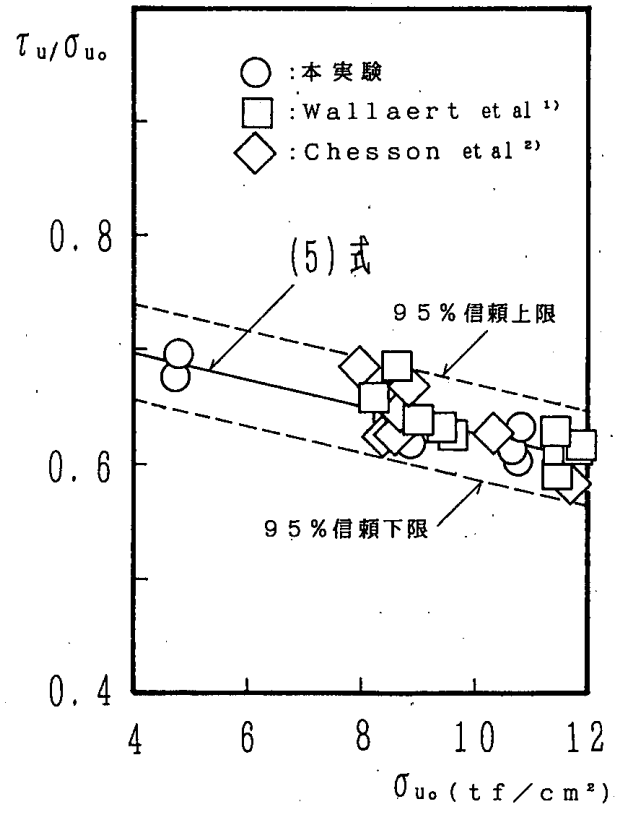

図一6 $\tau_{u} / \sigma_{u_{0}}-\sigma_{u_{0}}$ 関係 (AA 形, 既往実験デー夕を含む)

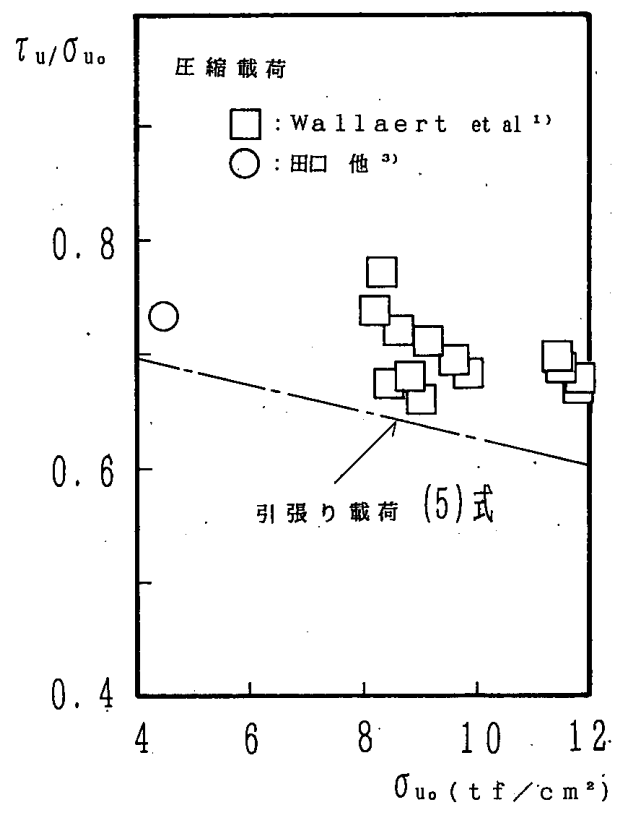

図一7 引張載荷と王縮載荷の比較
式の場合について前出の図一3に重ねてプロットしたも のである。はお，ボルトは ASTM 材であり，プロット したデー夕は同一実験の平均値である。これからも，本 報で算定した回帰式が十分妥当であると判断できる。

図一7 は, 同様に圧縮載荷の場合の既往の実験結果 ${ }^{1), 31}$ を示したものである。図中には比較のため引張載荷の場 合の回帰直線（5）式を示している。引張載荷の場合に 比べ, $\tau_{u} / \sigma_{u_{0}}$ の值がすべてのボルト素材の引張強さにわ たり大きくなっている。これは, 引張載荷の場合, 中板 が引張力により薄くなり, ボルトに曲げ応力の効果が入 り耐力が低下するのに対し，圧縮載荷では中板が厚くな り外板との摩擦抵抗が付加されるためであると推察され る。このことから, 圧縮載荷状態のボルトについては引
張載荷の場合の終局せん断強さの評価式を用いることで ボルトの終局せん断強さを安全側に評価できると言え る。

\section{4. ボルトの終局せん断強度評価式}

以上の実験結果および考察より，ばらつきを考慮して ボルトの終局せん断強さの評価を回帰式（5)〜（7）の $95 \%$ 信頼下限を採用することにすると次式となる。

$$
\begin{aligned}
& \tau_{\mathrm{AA}}=\left(0.702-1.17 \times 10^{-2} \times \sigma_{u_{0}}\right) \times \sigma_{u_{0}} \\
& \tau_{\mathrm{AC}}=\left(0.819-2.60 \times 10^{-2} \times \sigma_{u_{0}}\right) \times \sigma_{u_{0}} \\
& \tau_{\mathrm{cC}}=\left(0.992-5.22 \times 10^{-2} \times \sigma_{u_{0}}\right) \times \sigma_{u_{0}} \cdots
\end{aligned}
$$

ただし，本実験で使用したボルトの引張強さを考慮し， 適用範囲は次式とする。 
表一 6 終局せん断強さとボルト素材の引張り強さの比 $\left(\tau_{u} / \sigma_{u_{0}}\right)$

\begin{tabular}{|l|c|c|c|}
\hline \multirow{2}{*}{} & \multicolumn{3}{|c|}{ せん断面位圆 } \\
\cline { 2 - 5 } & A A 形 & A C 形 & C C 形 \\
\hline F 1 O T & 0.59 & 0.56 & 0.44 \\
\hline F 8 T & 0.61 & 0.61 & 0.57 \\
\hline $4 \mathrm{~T}$ & 0.65 & 0.71 & 0.78 \\
\hline
\end{tabular}

$4.0 \leqq \sigma_{u_{0}} \leqq 12.0\left(\mathrm{tf} / \mathrm{cm}^{2}\right)$

さらに，ボルトの終局せん断強度の評価式は，二面せ ん断の場合せん断面に対応した有効断面積を用いて次式 となる。

$$
\begin{aligned}
& Q_{A A}=2 A_{b} \times \tau_{A A} \cdots \ldots \\
& Q_{A C}=\left(A_{b}+A_{e}\right) \times \tau_{A C} \\
& Q_{C C}=2 A_{e} \times \tau_{C C} \cdots \cdots
\end{aligned}
$$

同様に, 一面せん断の場合の終局せん断強度評価式は 次式となる。

$$
\begin{aligned}
& Q_{A}=A_{b} \times \tau_{A A} \\
& Q_{C}=A_{e} \times \tau_{c C}
\end{aligned}
$$

ここで， $Q_{\Lambda} ， Q_{\mathrm{c}}$ はそれぞれ，せん断面が円筒部，ねじ 部の場合の終局せん断強度を示す。

なお, F 10T, F 8 T, 4 T レベルの SS 400 のボルト の終局せん断強さとボルト素材の引張強さの比 $\left(\tau_{u} / \sigma_{u_{0}}\right)$ をそれぞれの引張強さの公称値を用いて表すと表一 6 と なる。すなわち, 安全をみて $95 \%$ 信頼限界を考慮する とボルトの終局せん断強さの公称值は，ボルト素材の公 称引張強さにこれらの值を乗じたものを採用するのが妥 当である。

ただし，F $10 \mathrm{~T}$ ボルトのせん断面位置がねじ部の場 合については，引張強さの JIS 規定値である10１2 $\mathrm{tf} / \mathrm{cm}^{2}$ の範囲において $\tau_{u} / \sigma_{u_{0}}$ の低下率が引張強さの増 大率より上回るため, 安全を考虑し $(10)$ 式に $\sigma_{u}=12$ $\mathrm{tf} / \mathrm{cm}^{2}$ を代入したときの值を用いている。

\section{5. ボルトの終局時の引張りとせん断応力度の相関関係}

ボルトに軸方向の引張力とせん断力が同時に働く場合 の終局強度に関しては，文献2）にASTM A 325 と A 354 BD の高力ボルトの円筒部とねじ部に関し，それ ぞれ別々の式で実験式を与えている。これらの実験デー 夕から, 応力度に換算する際に，せん断面に対応した有 効断面積を用いたもので整理し直し，せん断面が円筒部 とねじ部それぞれについて, 縦軸に終局引張応力度とボ ルト素材の引張強さの比 $\left(\sigma_{\max } / \sigma_{u_{0}}\right)$, 横軸に終局せん 断応力度とボルト素材の引張強さの比 $\left(\tau_{\max } / \sigma_{u_{0}}\right)$ をとっ たものが，図一8 と図一9である。

これらより， $\sigma_{\max }=0$ の時 $\tau_{\max }=\tau_{u}$ であることから， $\tau_{u} / \sigma_{u_{0}}$ と 1.0 をそれぞれ短径の $1 / 2$, 長径の $1 / 2$ とする 楕円でボルトの終局強度に関する引張りとせん断応力度 の相関関係が与えられると判断できる。これを式で表す と次式となる。

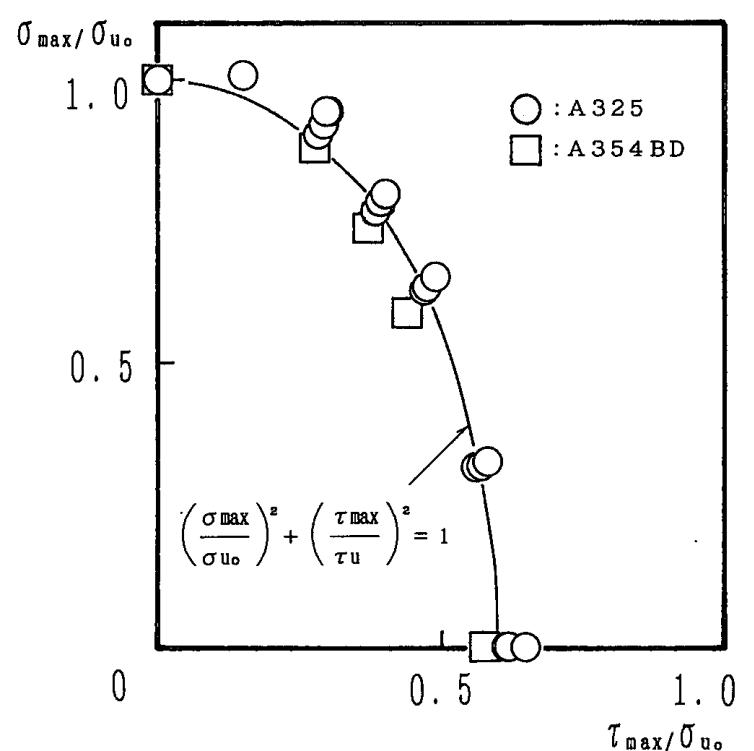

図一8 ボルトの終局強度に関する引張りとせん断応力度の相関 関係 (せん断面：円筒部)

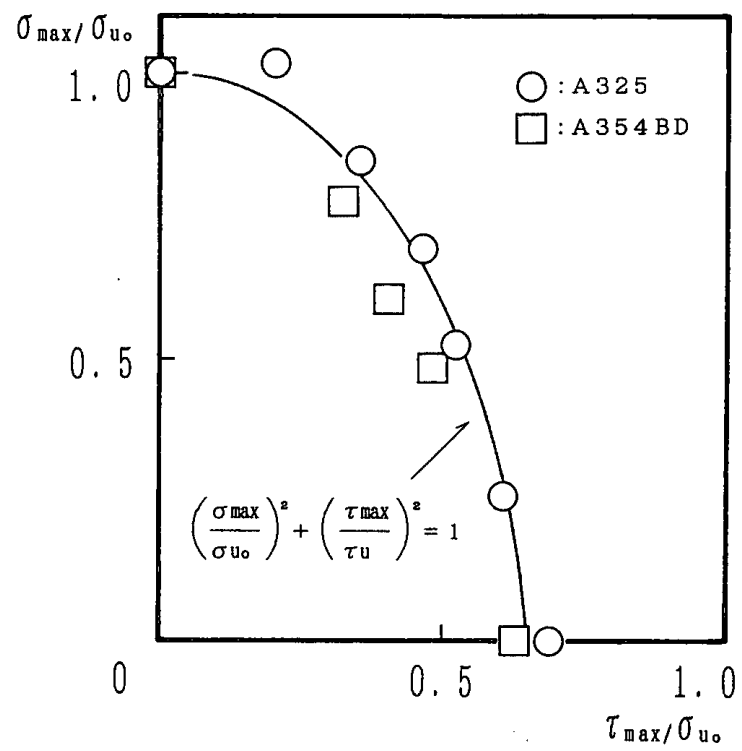

図一9 ボルトの終局強度に関する引張りとせん断応力度の相関 関係 (せん断面：ねじ部)

$$
\left(\sigma_{\max } / \sigma_{u_{0}}\right)^{2}+\left(\tau_{\max } / \tau_{u}\right)^{2}=1
$$

ここで， $\sigma_{\max }$ と $\tau_{\max }$ は組合せ応力時の終局引張応力度 と終局せん断応力度である。また， $\tau_{u}$ は式 $(8) \sim(10)$ による終局せん断強さである。

\section{6. ボルト初張力の影喓}

初張力導入時に降伏すると予想されるねじ部がせん断 面となる場合について，提唱した終局せん断強度評価式 が適用できるか否かを，ボルトの初張力の大きさを変数 としたせん断実験により検証した。

供試ボルトは，JSS II 09に規定されているトルシア 型高力ボルトS 10 T M 22×130を用いた。初張力の大 きさを実験変数とし, 初張力無しの $0 \mathrm{tf}$ からねじ部がほ ぼ全断面降伏する $1.4 B_{0}$ まで変化させた。ここで， $B_{0}$ 
表一7 試験体および実験結果一覧

\begin{tabular}{|c|c|c|c|c|c|}
\hline \multirow[b]{2}{*}{ ボルト } & \multirow[b]{2}{*}{ 世九断面 } & \multirow[b]{2}{*}{$\begin{array}{c}\text { ボルト初張力 } \\
\text { ( tf ) }\end{array}$} & \multicolumn{3}{|c|}{ 最大荷重時 } \\
\hline & & & $\begin{array}{c}\begin{array}{c}\text { ボルト張力 } \\
(\text { tf })\end{array} \\
\end{array}$ & $\begin{array}{c}\text { 最大せん断力 } \\
(\mathrm{t} i)\end{array}$ & $\tau \mathrm{u} / \sigma \mathrm{U}_{\mathrm{o}}$ \\
\hline $\begin{array}{l}1422 \\
\times 130\end{array}$ & A C 形 & $\begin{array}{l}0.08 \mathrm{Bo} \\
0.89 \mathrm{Bo} \\
0.98 \mathrm{Bo} \\
1.26 \mathrm{Bo} \\
1.39 \mathrm{Bo}\end{array}$ & $\begin{array}{l}0.26 \mathrm{Bo} \\
0.44 \mathrm{Bo} \\
0.63 \mathrm{Bo} \\
0.67 \mathrm{Bo} \\
0.60 \mathrm{Bo}_{0} \\
\end{array}$ & $\begin{array}{l}43.4 \\
44.8 \\
40.7 \\
43.4 \\
42.9 \\
\end{array}$ & $\begin{array}{l}0.576 \\
0.5994 \\
0.540 \\
0.576 \\
0.569\end{array}$ \\
\hline
\end{tabular}

$\mathrm{B}_{\mathrm{o}}=20.5 \mathrm{tf}$ (設計ボルト張力)

表一8 供試ボルトの機械的性質

\begin{tabular}{|c|c|c|c|c|}
\hline ホルト製㗊 & \multicolumn{4}{|c|}{4 号試盼片 } \\
\hline $\begin{array}{r}\text { 軸力口称校正值 } \\
\left(\times 10^{-6} / \mathrm{tf}\right)\end{array}$ & $\begin{array}{c}\text { 降伏点 } \\
\sigma y\left(\mathrm{tf} / \mathrm{cm}^{2}\right)\end{array}$ & $\begin{array}{c}\text { 引張強さ } \\
\sigma \mathrm{u}\left(\mathrm{tf} / \mathrm{cm}^{2}\right)\end{array}$ & $\begin{array}{l}\text { 伸ひ } \\
\operatorname{El}(\%)\end{array}$ & $\begin{array}{l}\text { 䋨り } \\
\phi(\%)\end{array}$ \\
\hline 127.5 & 10.60 & 11.03 & 18.7 & 66.2 \\
\hline
\end{tabular}

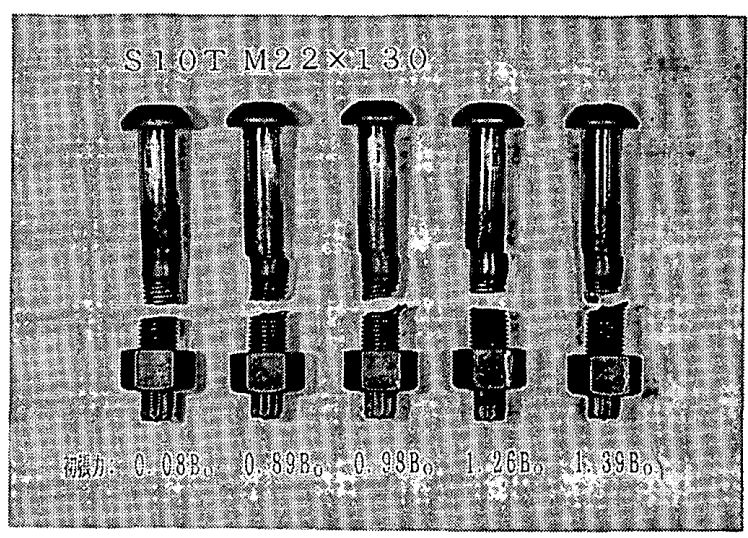

写真一4 ボルト破断状況（初張力の影響）

は設計ボルト張力である。初張力の導入は, ボルト円筒 部に添付したひずみゲージにより制御した。加力用鋼板 には SM 490 材を用い, 外板 $16 \mathrm{~mm}$, 中板 $22 \mathrm{~mm}$ の二 面せん断形式の試験体とし，ボルトの笲部とねじ部が 確実にせん断面になるように，ボルト頭側に座金を入れ て調整した。表一7に試験体の一覧を示す。また, 実験 による最大せん断力時に摩擦による付加抵抗が働かない ように, 摩擦面はペンキ仕上げのうえ潤滑油を塗布した。 なお，供試高力ボルト軸力ーひずみ校正結果と JIS Z 22014 号試験片による機械的性質を表一8に示す。

表一7に実験結果を, 写真一 4 にボルトの破断後の状 況を示す。このように試験体数は少ないが初張力の大き さによらず夷験による最大せん断力はほぼ同じとなっ た。

図一10 は，ボルトの終局せん断強さとボルト素材の 引張強さの比とボルト素材の引張強さの関係を示した前 出の図一4に, 初張力を導入した実験結果をプロットし たものである。いずれも $95 \%$ 信頼限界内であり, せん 断面が齐じ部の場合でも過度に塑性化させない限り初張 力の有無にかかわらず本報で提唱した終局せん断強度評 価式が適用できると判断できる。

図一11はせん断力とボル卜張力の関係を全試験体に ついて示したものである。縦軸は載荷時のせん断力を （6）(12）式による最大せん断力の計算值で除した值,

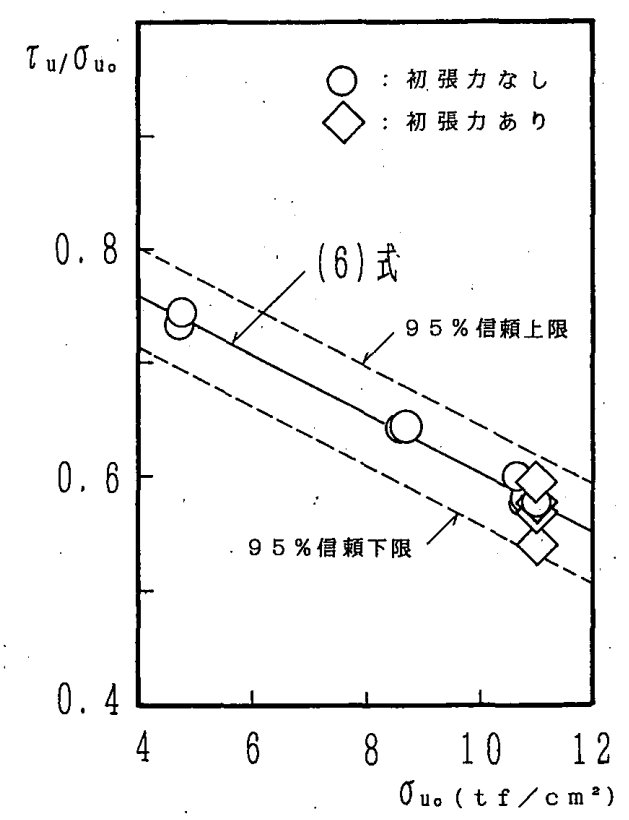

図-10 $\tau_{u} / \sigma_{u_{0}}-\sigma_{u_{0}}$ 関係 (AC 形, 初張力の影響)

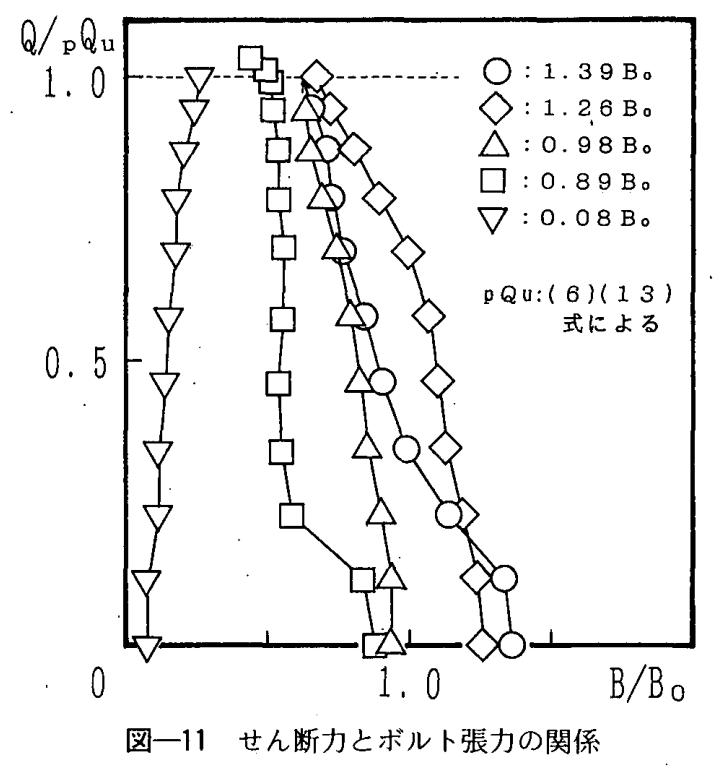

横軸はボルト張力を設計ボルト張力で除した値を示す。 このように最大せん断力に達したとき初張力を導入した ものはボルト張力が $0.44 B_{0} \sim 0.67 B_{0}$ 程度まで減少し, 一方初張力を入れないものでは $0.26 B_{0}$ にまで上昇する 現象を示している。これは，せん断面が円筒部の場合の 既往の実験9において，初張力の大きさによらず実験に よる最大せん断力時のボルト張力は $0.5 B_{0}$ 程度になる ことが示されており，本研究でも同様な傾向となった。 この現象が, ボルトの終局せん断強さに対し初張力の存 在があまり影響しないという結果の一因と推定できる。

\section{7. 結 論}

JIS B 1186 に規定される 1 種・2 種高力ボルトのセッ トでボルト径が M 16，M 20，M 22 のボルトの製品お よび JIS B 1180 の 4 T レベルの SS 400 の中ボルトの製 品に関しせん断実験を行い，既往の実験と合わせて以下 
の結論を得た。

1) ボルトの終局せん断強さの評価式はボルトの初張力 の有無にかかわらず，せん断面位置に応じて次式で表せ られる。

$$
\begin{aligned}
& \tau_{\mathrm{AA}}=\left(0.702-1.17 \times 10^{-2} \times \sigma_{u_{0}}\right) \times \sigma_{u_{0}} \\
& \tau_{\mathrm{AC}}=\left(0.819-2.60 \times 10^{-2} \times \sigma_{u_{0}}\right) \times \sigma_{u_{0}} \\
& \tau_{\mathrm{CC}}=\left(0.992-5.22 \times 10^{-2} \times \sigma_{u_{0}}\right) \times \sigma_{u_{0}}
\end{aligned}
$$

ただし， $4.0 \leqq \sigma_{u_{0}} \leqq 12.0\left(\mathrm{tf} / \mathrm{cm}^{2}\right)$

また，ボルトの終局せん断強度評価式は，せん断面位 置に対応した有効断面積を用いて次式となる。

$$
\begin{aligned}
& Q_{\mathrm{AA}}=2 \mathrm{~A}_{b} \times \tau_{\mathrm{AA}} \cdots \cdots \\
& Q_{\mathrm{AC}}=\left(\mathrm{A}_{b}+\mathrm{A}_{e}\right) \times \tau_{\mathrm{AC}} \\
& Q_{\mathrm{CC}}=2 \mathrm{~A}_{e} \times \tau_{\mathrm{CC}} \cdots \cdots \\
& Q_{\mathrm{A}}=\mathrm{A}_{b} \times \tau_{\mathrm{AA}} \cdots \cdots \cdots \\
& Q_{\mathrm{C}}=\mathrm{A}_{e} \times \tau_{\mathrm{CC}} \cdots \cdots \cdots
\end{aligned}
$$

2）ボルトの終局強度に関する軸方向引張りとせん断応 力度の相関関係は次式となる。

$$
\left(\sigma_{\max } / \sigma_{u_{0}}\right)^{2}+\left(\tau_{\max } / \tau_{u}\right)^{2}=1
$$

ここで, 終局せん断強さ $\left(\tau_{u}\right)$ はせん断面に応じて式 $(8)$ 〜（10）を用いる。

\section{参考文献}

1) JJ. Wallaert and J.W. Fisher : Shear Strength of HighStrength Bolts, Journal of the Structural Division,
ASCE, Vol. 91, ST3, pp. 99-125, 1965.6

2) E. Chesson, Jr., N. L. Faustino, and W.H. Munse : High-Strength Bolts Subjected to Tension and Shear, Journal of the Structural Division, ASCE, Vol.91, ST5, pp. 155 180, 1965.10

3）田口武一, 坂井正美, 山本次郎：引張り力を同時に受け るボルトのせん断実験（その1），日本建築学会大会学術 講演梗概集，pp. 1119 1120, 昭和 44 年 8 月

4）田口武一, 青木博文, 佐々木昌克：高力ボルト支圧接合 におけるボルトの剪断機構に関する基礎的研究，日本建 築学会大会学術講演梗概集, pp. 1049 1050, 昭和 49 年 10 月

5）橋本篤秀：高力ボルトの剪断強度, 日本建築学会大会学 術講演梗概集，pp. 1833 1834，昭和 57 年 10 月

6) 橋本篤秀：溶融亜鉛メッキボルト (F $8 \mathrm{~T} ・ 4 \mathrm{~T})$ の剪断 強度, 日本建築学会大会学術講演梗概集, pp. 1485 1486, 昭和 58 年 9 月

7) 橋本篤秀: F 10 T 高力ボルト単純引張り時の荷重・変形 性状, 日本建築学会構造系論文報告集, 第 309 号, pp. 11 20, 昭和 56 年 11 月

8）橋本篤秀：溶融亜鉛めっき高力ボルト（F８T) の単純引 張り時性状, 日本建築学会構造系論文報告集, 第 338 号, pp. 77 87, 昭和 59 年 4 月

9）田口武一, 坂井正美, 山本次郎：高力ボルト支王接合に 関する研究, 日本建築学会大会学術講演梗概集, pp. 871 $\sim 872$, 昭和 43 年 10 月

(1992 年 1 月 10 日原稿受理, 1992 年 7 月 6 日採用決定) 